\title{
Serum Glycated Albumin and GA/HbA1c Ratio as a New Markers of Glycemic Control in Children with Type 1 Diabetes Mellitus
}

\author{
Ashraf Mohamed Abdelfadil ${ }^{*}$, Laila El-Morsi Aboul-Fotoh ${ }^{1}$ and Aliaa Monir Higazi ${ }^{2}$ \\ ${ }^{1}$ Pediatric Department, Faculty of Medicine, Minia University, Egypt; ${ }^{2}$ Clinical Pathology Department, Faculty of Medicine, Minia \\ University, Egypt
}

\begin{abstract}
Introduction: Diabetes mellitus is a group of metabolic disorders characterized by hyperglycemia and accompanied by long term damage, dysfunction and failure of various organs. Several studies have shown that Glycated Albumin (GA) is more reliable DM monitor and a better marker of glycemic control in patients with fluctuating and poorly controlled type $2 \mathrm{DM}$. Moreover, serum GA is not affected by factors that affect hemoglobin metabolism.

The aim of the study: To study the value of serum glycated albumin as a new marker for glycemic control in diabetic children.

Methods: 30 diabetic children were included in the study in addition to 20, sex and age matched apparently healthy children as a control group. The associations among $\mathrm{HbA} 1 \mathrm{c}, \mathrm{GA}$, and $\mathrm{GA} / \mathrm{HbA} 1 \mathrm{c}$ ratio were examined, referred and managed in Children's Hospital, Minia University.

The results: Plasma glucose, GA and HbA1c measurements were done at baseline, after the 1 st and after the $3^{\text {rd }}$ months for all the subjects. GA levels strongly correlated with $\mathrm{HbA1c} \%$ in the diabetic group. The mean GA and $\mathrm{HbA1c}$ values were significantly lower in control group than in diabetic group ( $<0.001)$. GA, HbA1c and the ratio decreased significantly within 4 weeks, but GA showed a significantly larger decrease than HbA1c.

Conclusion: GA seems to be more accurately reflect short term glycemic control than HbA1c.

Keywords: Glycated albumin (GA); Hemoglobin A1C (HbA1c); Type 2 Diabetes Mellitus (T2DM)
\end{abstract}

\section{INTRODUCTION}

Diabetes Mellitus (DM) is a group of metabolic diseases characterized by hyperglycemia resulting from defects in insulin secretion, insulin action or both. The chronic hyperglycemia of diabetes is associated with long term damage, dysfunction, and failure of various organs, especially the eyes, kidneys, nerves, heart and blood vessels [1].

The use of diagnostic markers has shown that early diagnosis and treatment have the potential to prevent diabetic complications [2].

HbA1c is widely used for evaluation of long-term glycemic control and it provides an index of average blood glucose level during the past 2-3 months [3].
However, the use of HbA1c has some limitations as it may not be suitable for short term glycemic control and also in conditions that affect $\mathrm{Hb}$ metabolism as anemia [4].

\section{THE AIM OF THE WORK}

The aim of this work was to study the value of serum Glycated Albumin (GA) as a new marker for glycemic control in diabetic children.

\section{PATIENTS AND METHODS}

This case-control study had been carried out in the NICU of ElMinia University Hospital. Thirty diabetic children were recruited from the pediatric outpatient DM clinic and had already been diagnosed as diabetic patients for more than 6

"Correspondence to: Ashraf Mohamed Abdelfadeil, Assistant Professor of Pediatrics, Faculty of Medicine, Minia University, 521, 20th Street, Bolak El Dakror, Giza, Egypt, 12987, Tel: 00201068445424; E-mail: ashraf1191@yahoo.com

Received date: August 18, 2018; Accepted date: July 24, 2019; Published date: July 31, 2019

Citation: Abdelfadil AM, Aboul-Fotoh LE, Higazi AM (2019) Serum Glycated Albumin \& GA/HbA1c Ratio as a New Markers of Glycemic Control in Children with Type 1 Diabetes Mellitus. J Diabetes Metab 10:830.

Copyright: (C) 2019 Abdelfadil AM, et al. This is an open-access article distributed under the terms of the Creative Commons Attribution License, which permits unrestricted use, distribution, and reproduction in any medium, provided the original author and source are credited. 
months duration according to the standard ADA criteria [5], during the period from September 2017 to June 2019. Their ages ranged from $2-14$ years old (12 males and 18 females). In addition to 20 age and sex matched children ( 8 males and 12 females) were included as a control group. Patients excluded those who were anemic, and those with liver dysfunction, malignancy, thyroid diseases, diabetic complications, and patients on steroids.

All patients and controls were subjected to full history taking, including name, age, sex, residence, age of onset and duration of diabetes; and thorough clinical examination, including anthropometric measurements: (weight, height and body mass index) for each child and measures were plotted on the Egyptian Growth Charts (2002); where body weight obtained in kilogram and taken with the child in light clothes with no shoes. Height obtained in centimeters using Stadiometer. BMI was calculated according to the known formula; BMI=Weight $(\mathrm{kg}) /$ Height (m2); followed by complete systemic examination. Laboratory investigations, including the followings: Hb Level, Fasting blood sugar, postprandial blood sugar, fasting serum Glycated Albumin (GA), HbA1c serum level, and GA /HbA1c Ratio.

Investigations were done at the start of the study for both diabetic and control groups and during the follow-up visits after one month and after three months for the diabetic group.

Five $\mathrm{ml}$ of whole venous blood was withdrawn by a sterile vein puncture and divided into 3 tubes: one $\mathrm{ml}$ of venous blood was collected in EDTA containing tubes (Ethylene-diamine-tetraacetic acid) for glycated hemoglobin level; $2 \mathrm{ml}$ on a plain plastic tube were allowed to clot in the incubator at $37^{\circ} \mathrm{C}$ and after coagulation samples were centrifuged at $3000 \mathrm{rpm}$ for 10 minutes to obtain serum. Serum is then used for measuring glycated albumin level; and $2 \mathrm{ml}$ on a plain plastic tube were allowed to clot in the incubator at $37^{\circ} \mathrm{C}$ and after coagulation samples were centrifuged at $3000 \mathrm{rpm}$ for 10 minutes to obtain serum that is then used for measuring two hours post prandial blood sugar.

\section{Statistical methods}

The collected data were coded, tabulated, and statistically analyzed using SPSS program (Statistical Package for Social Sciences) software version 20 .

Descriptive statistics were done for parametric quantitative data by mean, standard deviation and minimum $\&$ maximum of the range, while they were done for categorical data by number and percentage.

Analyses were done for parametric quantitative data between the two groups using independent sample $t$ test, and for nonparametric quantitative data using Mann Whitney test, while they were done for qualitative data using Chi square test.

Analyses were done for parametric quantitative data within the same group at different time's using paired sample t test.

Correlation between two quantitative variables was done by using Pearson's correlation coefficient. Correlation coefficient ranges from (0-1):- weak $(r=0-0.24)$, fair $(r=0.25-0.49)$, moderate $(\mathrm{r}=0.5-0.74)$, strong $(\mathrm{r}=0.75-1)$. The level of significance was taken as ( $\mathrm{p}$ value $<0.05)$

The study was carried out according to the principles of declarations of Helsinki, and its appendices [6] and was approved the hospital ethical review board in El Minia university hospital (code 75a, March, 2015). Written informed consents from patients' caregivers were obtained for the use of their study-related information and for participation in the ongoing research.

\section{RESULTS}

Table 1 show that there is no significant difference between diabetic and control groups as regard demographic and anthropometric data, while there is a significant difference between both groups in percentile of both height and weight; and not in BMI percentile.

Table 1: Demographic and anthropometric data of diabetic and control group.

\begin{tabular}{|c|c|c|c|}
\hline & Diabetic group & Control group & \\
\hline & $(\mathrm{N}=30)$ & $(\mathrm{N}=20)$ & \\
\hline \multicolumn{4}{|l|}{ Age (years) } \\
\hline Range & $(3-15)$ & $(3-13)$ & \multirow{2}{*}{0.58} \\
\hline Mean \pm SD & $9.33 \pm 3.51$ & $8.8 \pm 2.98$ & \\
\hline \multicolumn{4}{|l|}{ Sex (no \%) } \\
\hline Male & $12(40 \%)$ & $12(60 \%)$ & \multirow{2}{*}{0.166} \\
\hline Female & $18(60 \%)$ & $8(40 \%)$ & \\
\hline \multicolumn{4}{|l|}{ Wt (kg) } \\
\hline Range & $(15-61)$ & $(15-50)$ & \multirow{2}{*}{0.792} \\
\hline Mean \pm SD & $36.43 \pm 12.02$ & $37.3 \pm 10.15$ & \\
\hline \multicolumn{4}{|c|}{ Wt Percentile } \\
\hline Range & $(24-98)$ & $(45-98)$ & \multirow{2}{*}{$0.012^{b}$} \\
\hline Mean \pm SD & $70.1 \pm 18.88$ & $83.8 \pm 17.24$ & \\
\hline \multicolumn{4}{|l|}{$\mathrm{Ht}(\mathrm{cm})$} \\
\hline Range & $(90-160)$ & $(92-158)$ & \multirow{2}{*}{0.614} \\
\hline Mean \pm SD & $131.83 \pm 20.81$ & $134.75 \pm 18.41$ & \\
\hline \multicolumn{4}{|c|}{ Ht Percentile } \\
\hline Range & $(2-93)$ & $(30-97)$ & \multirow{2}{*}{$0.001^{b}$} \\
\hline Mean \pm SD & $38.1 \pm 25.92$ & $63.6 \pm 21.51$ & \\
\hline
\end{tabular}




\begin{tabular}{lccc}
\hline Range & $(16.6-24.1)$ & $(17.5-24)$ & \multirow{2}{*}{0.813} \\
\cline { 1 - 2 } Mean \pm SD & $20.19 \pm 2.13$ & $20.34 \pm 1.97$ & \\
\cline { 1 - 2 } BMI $^{\mathrm{a}}$ Percentile & & & \\
\cline { 1 - 2 } Normal & $14(46.7 \%)$ & $6(30 \%)$ & \\
\cline { 1 - 2 } Overweight & $8(26.7 \%)$ & $7(35 \%)$ & \\
\cline { 1 - 2 } Obese & $8(26.7 \%)$ & $7(35 \%)$ & \\
\hline
\end{tabular}

\begin{tabular}{lccc}
\hline Range & $(3.6-5.5)$ & $(3.8-5.5)$ & \\
\hline Mean \pm SD & $4.54 \pm 0.41$ & $4.52 \pm 0.51$ & 0.87 \\
\hline HbA1c (\%) & & & \\
\hline Range & $(4.1-9.6)$ & $(4.5-6.4)$ & \\
\hline Mean \pm SD & $7.21 \pm 1.36$ & $5.62 \pm 0.52$ & $<0.001^{\mathrm{b}}$ \\
\hline GAa (\%) & & & \\
\hline Range & $(10.75-27.75)$ & $(6.6-14.2)$ & \\
\hline Mean \pm SD & $19.15 \pm 4.04$ & $11.08 \pm 2.11$ & $<0.001^{\mathrm{b}}$
\end{tabular}

\begin{tabular}{lccc}
\hline Range & $(45-99)$ & $(39-98)$ & \\
\cline { 1 - 2 } Mean \pm SD & $82.23 \pm 14.88$ & $85.5 \pm 16.55$ & \\
\hline
\end{tabular}

${ }^{a}$ Body mass index; ${ }^{b} \mathrm{p}$ value $<0.05$ is significant.

Table 2 shows that there is significant difference between diabetic and control groups as regards glycated albumin, glycated hemoglobin, fasting blood sugar, 2 hours postprandial and glycated albumin/glycated hemoglobin, but there is no significant difference between hemoglobin or albumin level between both groups.

Table 2: Laboratory data of diabetic and control group.

\begin{tabular}{cc} 
Diseased group & Control group \\
\cline { 1 - 2 }$(\mathrm{N}=30)$ & $(\mathrm{N}=20)$
\end{tabular}

\section{$\mathrm{Hb}(\mathrm{g} / \mathrm{dl})$}

\begin{tabular}{lccc}
\hline Range & $(9.9-14.3)$ & $(11-14.6)$ & \\
\hline Mean \pm SD & $12.21 \pm 1.13$ & $12.31 \pm 0.91$ & 0.76 \\
\hline
\end{tabular}

Albumin $(\mathrm{g} / \mathrm{dl})^{\mathrm{a}}$

Table 3: Comparison of laboratory data of diabetic group.

\section{GA/HbA1c Ratio ${ }^{c}$}

\begin{tabular}{lccc}
\hline Range & $(1.89-3.8)$ & $(1.46-2.21)$ & \\
\hline Mean \pm SD & $2.7 \pm 0.44$ & $1.94 \pm 0.2$ & $<0.001^{\text {b }}$
\end{tabular}

$\operatorname{FBS}(\mathrm{mg} / \mathrm{dl})^{\mathrm{d}}$

\begin{tabular}{|c|c|c|c|}
\hline Range & $(60-309)$ & $(70-125)$ & \\
\hline Mean \pm SD & $140.1 \pm 62.38$ & $97.7 \pm 15.69$ & $0.001^{\mathrm{b}}$ \\
\hline \multicolumn{4}{|c|}{$2 \mathrm{hrs} P P(\mathrm{mg} / \mathrm{dl})^{\mathrm{e}}$} \\
\hline Range & $(150-420)$ & $(118-182)$ & \\
\hline Mean \pm SD & $272.63 \pm 147.2$ & $156.5 \pm 16.41$ & $<0.001^{b}$ \\
\hline
\end{tabular}

Table 3 shows that there is a significant difference between serum levels of glycated hemoglobin at baseline and after three months, between after one month and after three months, and between baseline and after one month.

\begin{tabular}{|c|c|c|c|c|c|c|}
\hline & At baseline & After 1 month & After 3 months & P1 & P2 & P3 \\
\hline \multicolumn{7}{|l|}{ HbA1c (\%) } \\
\hline Range & $(4.1-9.6)$ & $(5-9.2)$ & $(4.9-9.8)$ & & & \\
\hline Mean \pm SD & $7.21 \pm 1.36$ & $7.13 \pm 1.18$ & $6.67 \pm 1.15$ & 0.483 & $0.046^{\mathrm{b}}$ & $0.036^{\mathrm{b}}$ \\
\hline \multicolumn{7}{|l|}{ GA $(\%)^{\mathrm{a}}$} \\
\hline Range & $(10.7-27.7)$ & $(7.7-23.25)$ & $(5.1-25.5)$ & & & \\
\hline Mean \pm SD & $19.15 \pm 4.04$ & $15.91 \pm 3.75$ & $14.83 \pm 4.48$ & $<0.001^{b}$ & $<0.001^{b}$ & $0.021^{b}$ \\
\hline \multicolumn{7}{|c|}{$\mathrm{GA} / \mathrm{HbA} 1 \mathrm{c}^{\mathrm{c}}$ ratio } \\
\hline Range & $(1.89-3.8)$ & $(1.45-3.16)$ & $(0.83-5.59)$ & & & \\
\hline
\end{tabular}




\begin{tabular}{|c|c|c|c|c|c|c|}
\hline Mean \pm SD & $2.7 \pm 0.44$ & $2.23 \pm 0.47$ & $2.36 \pm 0.82$ & $<0.001^{\mathrm{b}}$ & $0.013^{b}$ & 0.299 \\
\hline \multicolumn{7}{|l|}{ FBS $(\mathrm{mg} / \mathrm{dl})^{\mathrm{d}}$} \\
\hline Range & $(60-309)$ & $(70-267)$ & $(79-180)$ & & & \\
\hline Mean \pm SD & $140.1 \pm 62.3$ & $151.1 \pm 46.46$ & $119 \pm 28.19$ & 0.266 & 0.054 & $0.002^{b}$ \\
\hline \multicolumn{7}{|c|}{2 hrs $\operatorname{PP}(\mathrm{mg} / \mathrm{dl})^{\mathrm{e}}$} \\
\hline Range & $(150-420)$ & $(165-380)$ & $(144-331)$ & & & \\
\hline Mean \pm SD & $272.6 \pm 147$ & $273 \pm 62.1$ & $216 \pm 48.46$ & 0.985 & 0.064 & $<0.001^{\mathrm{b}}$ \\
\hline
\end{tabular}

${ }^{a}$ Glycated Albumin; ${ }^{b}$ p value $<0.05$ is significant; ${ }^{c}$ Glycated Albumin/Glycated Hemoglobin; ${ }^{\mathrm{d} F a s t i n g ~ B l o o d ~ S u g a r ;}{ }^{\mathrm{e} 2}$ Hours Postprandial.

There was a significant difference between glycated albumin measurement at base line and after one month, between base line and after three months and between the after one month and after three months.

Also, there is a significant difference between $\mathrm{GA} / \mathrm{HbA} 1 \mathrm{c}$ ratios between baseline and after one month, baseline and after three months.
There is a significant difference between FBS \& 2 hrs postprandial BS after one month and after three months.

Table 4 showed that there is a significant positive correlation between HbA1c measurements at baseline, after one month and after three months and the BMI of diabetic group.

Table 4: Correlation between HbA1c \& GA and clinical data of diabetic group.

\begin{tabular}{|c|c|c|c|c|c|c|c|c|c|c|c|c|}
\hline & \multirow{2}{*}{\multicolumn{2}{|c|}{$\begin{array}{l}\text { HbA1c } \\
\text { Baseline }\end{array}$}} & \multicolumn{2}{|c|}{$\mathrm{GA}^{\mathrm{a}}$} & \multicolumn{2}{|c|}{$\mathrm{HbA} 1 c^{\mathrm{b}}$} & \multicolumn{2}{|c|}{ GA } & \multicolumn{2}{|c|}{$\mathrm{HbA1}^{\mathrm{c}}$} & \multicolumn{2}{|c|}{ GA } \\
\hline & & & & line & After & month & After & month & After & month & Aft & month \\
\hline & $\mathrm{R}$ & $\mathrm{p}$ value & $\mathrm{R}$ & $\mathrm{p}$ value & $\mathrm{R}$ & $\mathrm{p}$ value & $\mathrm{R}$ & $p$ value & $\mathrm{R}$ & $\mathrm{p}$ value & $\mathrm{R}$ & $p$ value \\
\hline $\mathrm{Hb}$ & 0.058 & 0.762 & 0.024 & 0.9 & 0.012 & 0.952 & $0.02^{c}$ & 0.89 & 0.215 & 0.253 & 0.07 & 0.685 \\
\hline Albumin & 0.081 & 0.669 & 0.152 & 0.423 & 0.023 & 0.905 & -0.084 & 0.658 & 0.089 & 0.638 & -0.06 & 0.732 \\
\hline Age & -0.185 & 0.328 & 0.054 & 0.779 & -0.207 & 0.273 & 0.026 & 0.89 & 0.158 & 0.404 & 0.113 & 0.552 \\
\hline Wt (kg) & 0.037 & 0.845 & 0.264 & 0.158 & 0.025 & 0.894 & 0.143 & 0.45 & 0.338 & 0.067 & 0.269 & 0.15 \\
\hline $\mathrm{Ht}(\mathrm{cm})$ & -0.22 & 0.243 & 0.049 & 0.797 & -0.255 & 0.174 & 0.022 & 0.906 & 0.18 & 0.34 & 0.13 & 0.492 \\
\hline $\mathrm{BMI}^{\mathrm{d}}$ & 0.632 & $<0.001$ & 0.536 & $0.002^{c}$ & 0.595 & $0.001^{c}$ & 0.21 & 0.266 & 0.47 & $0.009^{c}$ & 0.37 & $0.044^{c}$ \\
\hline $\mathrm{DM}(\mathrm{yrs})^{\mathrm{e}}$ & -0.055 & 0.773 & 0.137 & 0.47 & -0.103 & 0.588 & 0.053 & 0.78 & -0.035 & 0.856 & 0.146 & 0.44 \\
\hline
\end{tabular}

${ }^{a}$ Glycated Albumin; ${ }^{b}$ Glycated Hemoglobin; ${ }^{c}$ p value $<0.05$ is significant; ${ }^{\mathrm{d} B o d y}$ Mass Index; ${ }^{\mathrm{e}}$ duration of Diabetis Mellitus in years.

There is a significant positive correlation between GA measurements at baseline and after three months and the BMI of diabetic group; while that at one month is not positively correlated.

There is no significant correlation between GA and age, weight, height, duration of diabetes, $\mathrm{Hb}$ or albumin levels.
Table 5 shows that there is significant positive correlation between $\mathrm{HbA} 1 \mathrm{c}$ measurements at baseline and that after one month and after three months. 
Table 5: Correlation between HbA1c and studied laboratory data of diabetic group at baseline and during follow up visits.

\section{$\mathrm{HbA1}^{\mathrm{a}}$}

\begin{tabular}{cccccc}
\hline Baseline & After 1 month & After 3 months \\
\hline $\mathrm{R} \quad$ p value & $\mathrm{R}$ & $\mathrm{p}$ value & $\mathrm{R}$ & $\mathrm{p}$ value
\end{tabular}

\section{HbA1c}

\begin{tabular}{lllccc}
\hline Baseline & & 0.893 & $<0.001^{\mathrm{d}}$ & 0.37 & $0.040^{\mathrm{d}}$ \\
& & & & & \\
\hline $\begin{array}{l}\text { After 1 } \\
\text { month }\end{array}$ & 0.893 & $<0.001^{\mathrm{d}}$ & & 0.52 & $0.003^{\mathrm{d}}$ \\
\hline
\end{tabular}

\begin{tabular}{lllll}
\hline $\begin{array}{l}\text { After } 3 \\
\text { months }\end{array}$ & 0.377 & $0.040^{\mathrm{d}}$ & 0.525 & $0.003^{\mathrm{d}}$ \\
\hline
\end{tabular}

GA b

\begin{tabular}{lcccccc}
\hline Baseline & 0.605 & $<0.001^{\mathrm{d}}$ & 0.646 & $<0.001^{\mathrm{d}}$ & $\begin{array}{c}0.59 \\
2\end{array}$ & $0.001^{\mathrm{d}}$ \\
\hline $\begin{array}{l}\text { After 1 } \\
\text { month }\end{array}$ & 0.372 & $0.043^{\mathrm{d}}$ & 0.47 & $0.009^{\mathrm{d}}$ & $\begin{array}{c}0.55 \\
2\end{array}$ & $0.002^{\mathrm{d}}$ \\
\hline $\begin{array}{l}\text { After 3 } \\
\text { months }\end{array}$ & 0.32 & 0.084 & 0.445 & $0.014^{\mathrm{d}}$ & 0.70 & $<$ \\
\hline
\end{tabular}

\section{GA/ HbA1c Ratio ${ }^{c}$}

\begin{tabular}{lcccccc}
\hline Baseline & -0.293 & 0.116 & -0.225 & 0.232 & $\begin{array}{c}0.17 \\
2\end{array}$ & 0.363 \\
\hline $\begin{array}{l}\text { After 1 } \\
\text { month }\end{array}$ & -0.248 & 0.187 & -0.258 & 0.169 & $\begin{array}{c}0.22 \\
2\end{array}$ & 0.237 \\
\hline $\begin{array}{l}\text { After 3 } \\
\text { months }\end{array}$ & -0.02 & 0.917 & 0.036 & 0.85 & $\begin{array}{c}0.26 \\
9\end{array}$ & 0.151 \\
\hline
\end{tabular}

${ }^{a}$ Glycated Hemoglobin; ${ }^{b}$ Glycated Albumin; 'Glycated Albumin/ Glycated Hemoglobin Ratio; ${ }^{\mathrm{d}} \mathrm{p}$ value $<0.05$ is significant.

There is significant positive correlation between $\mathrm{HbA1c}$ measurements at baseline, after one month and after three months and GA measurements at baseline and after one month. But, there is no correlation between $\mathrm{HbA1c}$ at baseline and GA measurement after 3 months.

But there is no any significant correlation between $\mathrm{HbA1c}$ measurements and $\mathrm{GA} / \mathrm{HbA} 1 \mathrm{c}$ ratio at three measurements.

Table 6 shows that there is a significant positive correlation between $\mathrm{HbA1c}$ measurements at baseline and between GA measurements at baseline and after one month.
Table 6: Correlation between GA and studied laboratory data of diabetic group.

\begin{tabular}{|c|c|c|c|c|c|c|}
\hline & \multicolumn{6}{|c|}{ Glycated Albumin } \\
\hline & \multicolumn{2}{|c|}{ Baseline } & \multicolumn{2}{|c|}{ After 1 month } & \multicolumn{2}{|c|}{ After 3 months } \\
\hline & $\mathrm{R}$ & $\mathrm{p}$ value & $\mathrm{R}$ & $\begin{array}{c}\mathrm{p} \\
\text { value }\end{array}$ & $\mathrm{R}$ & $\mathrm{p}$ value \\
\hline \multicolumn{7}{|l|}{$\mathrm{HbA1} \mathrm{c}^{\mathrm{a}}$} \\
\hline Baseline & 0.605 & $<0.001^{\mathrm{d}}$ & 0.372 & $0.043^{\mathrm{d}}$ & 0.32 & 0.084 \\
\hline $\begin{array}{l}\text { After } 1 \\
\text { month }\end{array}$ & 0.646 & $<0.001^{\mathrm{d}}$ & 0.47 & $0.009^{d}$ & 0.445 & $0.014^{\mathrm{d}}$ \\
\hline $\begin{array}{l}\text { After } 3 \\
\text { months }\end{array}$ & 0.592 & $0.001^{\mathrm{d}}$ & 0.552 & $0.002^{\mathrm{d}}$ & 0.704 & $<0.001^{d}$ \\
\hline \multicolumn{7}{|l|}{$\mathrm{GA}^{\mathrm{b}}$} \\
\hline Baseline & & & 0.798 & $<0.001$ & 0.736 & $<0.001^{*}$ \\
\hline $\begin{array}{l}\text { After } 1 \\
\text { month }\end{array}$ & 0.798 & $<0.001$ & & & 0.844 & $<0.001^{*}$ \\
\hline $\begin{array}{l}\text { After } 3 \\
\text { months }\end{array}$ & 0.736 & $<0.001$ & 0.844 & $<0.001$ & & \\
\hline
\end{tabular}

\section{GA/HbA1c Ratio}

\begin{tabular}{lcccccc}
\hline Baseline & 0.492 & $0.006^{\mathrm{d}}$ & 0.506 & 0.004 & 0.436 & $0.016^{\mathrm{d}}$ \\
\hline $\begin{array}{l}\text { After 1 } \\
\text { month }\end{array}$ & 0.335 & 0.07 & 0.639 & $<0.001$ & 0.579 & 0.001 \\
\hline $\begin{array}{l}\text { After 3 } \\
\text { months }\end{array}$ & 0.401 & $0.028^{\mathrm{d}}$ & 0.556 & 0.001 & 0.691 & $<0.001^{\mathrm{d}}$ \\
\hline
\end{tabular}

aGlycated Hemoglobin; 'blycated Albumin; 'Glycated Albumin/ Glycated Hemoglobin Ratio; ${ }^{d}$ p value $<0.05$ is significant.

There is significant correlation between GA measurements at baseline and GA measurements after one month and three months.

Also, there is a significant positive correlation between GA measurements at baseline and after one month and between base line $\mathrm{HbA} 1 \mathrm{c} / \mathrm{GA}$ ratios.

There is a significant positive correlation between GA measurements after one month and after three months and after one-month $\mathrm{HbA1c/GA}$ ratio.

There is a significant positive correlation between GA measurements at baseline, after one month and after three months and after three months HbA1c/GA ratio. 
But there is no any correlation between $\mathrm{HbA1c}$ measurements at baseline and GA measurement after three months.

No correlation between GA measurement after three months and base line $\mathrm{HbA} 1 \mathrm{c} / \mathrm{GA}$ ratio.

Also, there is no correlation between baseline GA measurement and after one-month HbA1c/GA ratio.

\section{DISCUSSION}

The combination of severe insulin deficiency and physical and psychosocial changes makes the management of children T1DM difficult [7].

Many studies have left areas of uncertainty about HbA1c; the most widely used marker of glycemic control over the preceding 2 to 3 months; Glucose levels during the 30 days before the test have the biggest impact on $\mathrm{HbA1c}$, variability of RBCs lifespan affects the HbA1c levels and also the turnover of HbA1c is very slow because of the long half-life of hemoglobin [8].

Also, it is possible that diabetic individuals with disease duration<3 months would be missed if tested by HbA1c (Lower sensitivity and accuracy) [9].

HbA1c can be influenced by various clinical factors such as anemia (by increasing the proportion of young erythrocytes in the blood and reduced red-blood cell lifespan), recent transfusion, iron deficiency, metabolic acidosis or frequent erythropoietin injection [10].

Compared to $\mathrm{HbA1c}$, GA responds much sooner to changes in glycemic levels, reflecting short-term glycemic control over the previous 2 to 3 weeks [11].

In our study, there was a significant difference in weight and height percentile but not in anthropometric data between diabetic and control group. This was in agreement with Satyavani, et al., [12]. Also, Furusyo et al., agreed with us as regards that both of GA and HbA1c was not influenced by sex and they found that GA measurements can be used to screen for diabetes regardless of age and sex [13].

In the first follow up visit for the patients in our study, both GA and $\mathrm{GA} / \mathrm{HbA} 1 \mathrm{c}$ ratio decreased significantly, while $\mathrm{HbA1c}$ not significantly decreased.

Takahashi et al., \& Inaba et al., reported that both GA and $\mathrm{HbA} 1 \mathrm{c}$ and the ratio decreased significantly at 16 weeks than at baseline and GA showed a significantly larger percent decrease than HbA1c. The rapid decrease in GA reflects the faster turnover of plasma albumin than that of $\operatorname{RBC}[10,14]$.

Koga et al., agreed with us about the positive correlation between HbA1C and BMI [15], and Yoshiuchi et al., agreed with us about the positive correlation between GA and BMI, in childhood T1DM in Japan [16]. While Wang et al. found an inverse relationship between BMI and GA [17].

Takahashi et al. and Selvin et al. agreed with us about the strong relationship between BS readings both FBS and PPS, and both HbA1C \& GA $[10,18]$.
Also, our study agreed with Woo et al., about no correlation of GA and serum albumin level [19] and with Miyashita et al., who studied GA levels in obese T2DM .

Koga et al. reported that serum GA levels could be affected by various conditions with abnormal metabolism of albumin. Under certain conditions with shortened albumin metabolism, such as hyperthyroidism, nephrotic syndrome or administered glucocorticoid treatments, serum GA levels are apparently low, whereas it may be high when albumin metabolism is prolonged, as in liver cirrhosis [15].

In our study there was a positive correlation between GA levels and GA/HbA1c ratio and HbA1c levels. This is in agreement with Takahashi et al. study in type 2 diabetic patients [10].

\section{CONCLUSION}

This prospective study suggests that GA \& GA/HbA1c Ratio are a useful markers for assessing short term glycemic changes in children with type1 diabetes mellitus. They are useful in the assessment of the early improvement of T1DM under treatment.

\section{RECOMMENDATIONS}

- Use of GA for short term glycemic control in diabetic children to avoid complication of hypoglycemic and hyper glycemic complications in children.

- GA should be used in glycemic control in diabetic children with anemia, haemodialysis and haemoglobinopathies.

\section{ACKNOWLEDGMENT}

To all medical personnel including doctors and nurses who are working in endocrinal unit and clinico pathological lab for helping us in our research work.

\section{REFERENCES}

1. Craig ME, Hattersley A, Donaghue KC. Definition, epidemiology and classification of diabetes in children and adolescents. Pediatr Diabetes. 2009;10:3-12.

2. Chen PC, Bry L, Sacks DB. Effects of Hemoglobin variants \&chemically modified derivatives on assays for glycohemoglobin. Clin Chem. 2001;47:135-163.

3. Jeffcoate SL. Diabetes control and complications: the role of glycated hemoglobin, 25 years on. Diabet Med. 2004;21(7):657665.

4. Song MK, Bae JW, Klim YH, Chung S. Hemoglobin A1C in the screening of obesity-related diseases in children and adolescents. Ann Pediatr Endocrinal Metab. 2012; 17:92-99.

5. American Diabetes Association. Diagnosis and classification of diabetes mellitus. Diabet Care. 2001;35(1):64-71.

6. World Medical Association Declaration of Helsinki Ethical Principles for Medical Research involving human subjects.

7. Sharp P, Rainbow S. Continuous glucose monitoring and haemoglobin A (1c). Ann Clin Biochem. 2002;39:516-517.

8. Chujo K, Shima K, Tada H, Oohashi T, Minakuchi J, Kawashima $\mathrm{S}$. Indicators for blood glucose control in diabetics with end-stage chronic renal disease: GHb vs. Glycated albumin (GA). J Med Invest. 2006;53:223-228.

9. Yamaguchi M, Kambe S, Eto T, Yamakoshi M, Kouzuma T, Suzuki N. Point of care testing system via enzymatic method for the rapid, 
efficient assay of glycated albumin. Biosens Bioelectron. 2005;21:426-432.

10. Takahashi S, Uchino H, Shimizu T, Kanazawa A, Tamura Y, Suzuki N. Comparison of glycated albumin (GA) and glycated hemoglobin $(\mathrm{HbA} 1 \mathrm{c})$ in diabetic patients: usefulness of GA for evaluation for short-term changes in glycemic control. Endocr J. 2007;54(1):139-144.

11. Kumpatla S, Tilak P, Viswanathan V. Efficacy of Glycated Albumin (GA) in Comparison with Glycated Hemoglobin (HbA1c) in Type 2 Diabetic Subject in India. JK Science. 2011;13(1):6-10.

12. Furusyo N, Koga T, Ai M, Otokozawa S, Kohzuma T, Ikezaki H, et al. Utility of glycated albumin for the diagnosis of diabetes mellitus in a Japanese population study: results from the Kyushu and Okinawa Population Study (KOPS). Diabetologia. 2011;54:3028-3036.

13. Inaba M, Okuno S, Kumeda Y, Yamada S, Imanishi Y, Tabata T, et al. Glycated albumin is a better glycemic indicator than glycated hemoglobin values in hemodialysis patients with diabetes: effect of anemia and erythropoietin injection. J Am Soc Nephrol. 2007;18(3):896-903
14. Koga M, Hirata T, Kasayama S, Ishizaka Y, Yamakado M. Clinical impact of glycated albumin as another glycemic control marker. Clin Chim Acta. 2015;438:19-23.

15. Yoshiuchi K,Yamamoto Y, Akabayashi A. Application of ecological momentary assessment in stress-related diseases. Biopsychosoc Med. 200811;2:13.

16. Wang F, Ma X, Hao Y, Yang R, Ni J, Xiao Y, et al. Serum glycated albumin is inversely influenced by fat mass and visceral adipose tissue in Chinese with normal glucose tolerance. PLoS One. 2012;7(11): e51098.

17. Selvin E, Steffes MW, Hong Zhu BS, Matsushita K, Wagenknecht L, Pankow J, et al. Glycated Hemoglobin, Diabetes, and Cardiovascular Risk in Nondiabetic Adults. $N$ Eng $M$ J. 2010;362:800-811.

18. Lee JW, Kim HJ, Kwon YS, Jun YH, Kim SK, Choi JW, et al. Serum glycated albumin as a new glycemic marker in pediatric diabetes. Ann Pediatr Endocrinol Metab. 2013;18:208-213.

19. Miyashita Y, Nishimura R, Morimoto A, Matsudaira T, Sano H, Tajima N, et al. Glycated albumin is low in obese, type 2 diabetic patients. Diabetes Res Clin Pract. 2007;78(1):51-55. 